\title{
The Influence of "Problem-Posing" Learning Model To Activities and Learning Outcomes In Elementary School
}

\author{
A. Setiawan, K. Prasetyo, and M. T. Yani \\ Universitas Negeri Surabaya \\ Surabaya, Indonesia \\ Anggasetiawan25.as@gmail.com
}

\begin{abstract}
The problem is the dominant role of the teacher in teaching and learning activities so students become less active in the learning process. As a result, the researcher needs a learning model that makes students more active and the learning results will increase. One of the ways is by using the Problem Posing learning model. The study aims to describe how many influences of Problem Posing learning model on activities and learning outcomes of Social Science subjects for 4th Grader's students in elementary school. The research method is quantitative with a quasi-experimental research type. The result of the t-Test on learning activity obtained as count $>$ table that is $3.43>2.09$ whereas the result of $t$-Test on learning outcomes obtained as $t$ count $>t$ table that is $3.29>2.09$. So it can be concluded that there is a significant influence of Problem Posing learning model on activities and learning outcomes.
\end{abstract}

Keywords-Problem Posing model; activities learning; learning outcomes.

\section{INTRODUCTION}

Education in elementary schools is an early stage for continuing study to a higher level and is also a modality of life when socializing in community. Therefore, education in elementary schools allegedly has not indicated the direction of independent learning that can make the students aware that the essence of study in school is as an initial capital in socializing within society. This is also reinforced by Law Number 20 the Year 2003 on National Education System, Article 3, the purpose of national education is to develop the learner's potential who possessed noble character, knowledgeable, creative, independent, and become democratic citizens and responsible. Schools as an education organizer are very influential and certainly become the main object as the target of all parties both parents, community and bureaucratic who also get the impact directly. In addition, the teacher also plays an important role in the school learning, therefore an optimal learning process and conducive is essential. The ability of individuals to produce creative outcomes includes the process of learning, a teacher needs to create a conducive classroom atmosphere, so that will increase student high activity and optimal learning outcomes [1].
Social study (IPS) education is a discipline in social sciences and humanity, as to organize basic human activities and to present scientifically and psychologically for educational purposes. A social study is one of the subjects given to elementary school children because it's a lesson that includes events, facts, concepts which are related to social issues existing in society. In primary school learning, it is hoped that there will be innovative teachers to help the learning process to create effective, efficient and fun learning. So it can help students think and understand the material provided by the teacher. Teachers should think about how to keep students focused on the learning process undertaken. There are various components as a supporting factor in the learning process, including media, methods, strategies, approaches and learning models. The application of learning model, as an example, for educational activities will be needed in the context of teaching and learning activities. Because with a scientific, systematic and rational approach, it is relevant to achieve the goal of effective and efficient education. From the results of early observations and interviews that were conducted by researchers showed that some teachers in implementing learning were applied STAD model. In this case, there are some problems that arise that STAD model is still bound by the ability of teachers and students to be less active in learning. These problems resulting in lack of optimal student activity and learning outcomes [2].

When teachers ask students to ask questions about learning problems, students were still passive (silent and confused in search of questions from textbooks). In group activities, there were many students who only rely on their friends while doing the tasks assigned by the teacher and have not seen the activeness of students in the opinion or respond to the problems that have been submitted. The activeness of students in the class affects the learning process so that students are able to absorb the learning materials. Learning outcomes also need to be optimized considering the results of learning is an indicator to know the success of student learning. From the outlined problems above, it needs to be made improvements in learning activities. Whereas teachers should provide opportunities for students to play a more active 
role in the learning process and presents a real problem for students. This is in addition to increasing student activity to learn directly, students will understand the material learned better and it will improve student learning outcomes. Improved learning outcomes are one indicator of achievement of educational goals that cannot be separated from the student's motivation and creativity of teachers in presenting a subject matter through various learning models to achieve maximum teaching objectives [3]

One of the efforts to increase student's activity and learning outcome in the social study (IPS) learning in this research, the researcher will use Problem Posing as a learning model. In the Problem Posing learning process, learning begins with the filing of problems or questions of learners based on existing information. In its implementation, this learning helps learners in formulating a problem based on the topic or material that has been described by the teacher, to make it more deeply it will be accompanied by the problemsolving. Problem Posing learning model has several advantages such as can increase student's activity so they more active in learning, not easy to give up, confident and have thought about solving a problem. Based on that background, then researcher conducted a research entitled "The effect of Problem Posing Learning Model to Activities and Learning Outcomes in Social Study (IPS) Subjects for fourth-grade Elementary School Students". From the above explanation, then the problems identified in this research was student's activity and learning outcomes using Problem Posing learning model of fourth-grade student of SDN I Bogoran Trenggalek. This study objective was to describe the significant activities and learning outcomes of social study (IPS) between students using Problem Posing learning model and students who using STAD learning model in the recognizing economic activities related to natural resources material and other potentials in the area of fourth grade student of SDN I Bogoran Trenggalek [4]

In relation to the problems identified in this study, a model has a major role in the success of learning. A model is a form of accurate representation as an actual process that allows a person or group of person to try an act based on the model. The learning model is a plan or pattern that can be used as a guide in planning learning in the classroom or learning tutorial and to determine learning tools. "Posing Problem" is a learning model derived from the UK, with the approach of problem posing. In English meaning, "problem" which means a problem and posing from the word "pose" which means formulation, submission or formation. So it can be concluded by the term that Problem Posing means the formation of problems or pose a problem. In the Problem Posing learning process, learning begins with the posing of problems or questions from learners based on existing information. In the implementation of this learning, it helps learners in formulating a problem based on the topic or material that has been explained by the teacher so that it's more deeply accompanied by the solution. The position of teachers in Problem Posing learning is as a facilitator, teachers play a role in delivering students in understanding the concept by preparing the situation with the subject taught, then from the situation, students construct as many problems as possible in order to more understand about the concept. The student is a subject in learning Problem Posing because this is a studentcentred learning where the student is the centre of learning. Students must play an active role in formulating and finding solutions to these questions. In this study, the class will tend to be noisy because learning more emphasized in the discussion activities, in addition to the time allocation must also be taken into account the teacher well, the use of language is also very influential at the time of formulation of questions and analyze the solution. For that teacher is a very important role as a facilitator, it needs a good class organizing skills for teachers to make Problem Posing learning work well [5].

Problem Posing learning has the following characteristics: (1) teachers learn from students and students learn from teachers, (2) teachers become fellow students who involve themselves and stimulate the critical thinking power of their students and humanize each other, (3) human can develop its ability to critically understand itself and the world its belong. (4) Problem Posing learning always reveals the secrets of reality that challenge human and then demand a response to those challenges. Response to the challenge of opening human to full dedication. The Problem Posing learning steps are: 1) initiating the learning activities, 2) deliver the learning objectives, 3) ask learners to do prereading about the material to be studied, 4) explaining the subject matter, 5) giving examples of problem, 6) giving the opportunity to the students to ask questions about the unclear, 7) to form learners into groups, 8) teachers submit statements that will be made into questions to or problems 9) provide opportunities for students to form problem and solve it by discussing group, 10) directs students to make conclusions, 11) summarizes based on conclusion, 12) closes learning activities [6].

The advantages of the Problem Posing learning model include: a) students can be involved during the learning process (active), b) teach students to be critical, c) teach not to give up and despair in the face of a problem, d) educate children to believe in their own selves, e) bring pride if other groups/people cannot work to the questions we have formulated, f) help students gain a better understanding. The learning process will not be separated from the interaction relationship between teachers and learners. The interaction between teachers and learners will be seen through the activities they do. Proposed that learning activities basically is a process of behaviour change due to the experience of learning. Changes to the intended behaviour include changes in understanding, knowledge, attitudes, skills, habits and appreciation. While the experience itself in the learning process is the occurrence of interaction between individuals and their environment [7].

In the learning process, teachers have the task to provide knowledge, attitudes and values, and skills to learners. Teachers have a responsibility to see everything that happens 
in the classroom to help learner's developmental process. The delivery of learning materials is one of the teacher's activities in learning as a dynamic process in all phases and learners development. Stated that in the learning process teacher need to generate a learner's activity in thinking and doing. Learner's activity in learning has a various form, from physical activity that is easily observed until the psychic activity that difficult to observe[8].

Physical activity that can be observed such as activities in the form of reading, listening, writing, modelling and measuring. While examples of psychic activities such as recalling the contents of the subject matter in the previous discovery, using the repertoire of knowledge to solve the problem, concluding the results of experiments, comparing one concept with another concept. Learning process conducted by a teacher with the objective of achieving good learning outcomes. Good learning outcomes can be achieved if the learning was done optimally. Student's learning outcomes are the ability that has been obtained by the student after attending learning activities that existed in schools, in the family and in the community. Identifies several factors that can affect learning outcomes into ten type of intelligence namely, child readiness, child talent, learning willingness, child interests, material presentation models, teacher's personality and attitudes, learning atmosphere, teacher's competence and conditions of society. Of the ten factors that can affect a student's learning outcomes almost completely are the child's intelligence, child's readiness, child's talent. Factors that affect partially depend on the teacher namely the ability factor (competence), learning atmosphere and teacher's personality[9].

The formulation of the problem in this study is:

1. Is there an influence on the application of the Problem Posing learning model on student learning activities in social studies in fourth-grade elementary school?

2. Is there an influence on the application of Problem Posing learning models on student learning outcomes in social studies in fourth-grade elementary school?

The objectives to be achieved in this study is:

1. To analyze the effect of applying the Problem Posing learning model on student learning activities in social studies subjects in grade IV elementary school.

2. To analyze the effect of applying the Problem Posing learning model on student learning outcomes in social studies subjects in grade IV elementary school.

\section{METHOD}

The type of research applied was the quantitative research. The research design used was an experiment. The experiment used in this research was Quasi-Experimental Design. In Quasi-Experimental Design has a control group, but it is not fully functional to control the outside variables that affect the implementation of the experiment. This experimental form is a development of true experimental design, which is difficult to implement. The design used in this research was nonequivalent control group design. Nonequivalent control group design is similar to pretestposttest control group design, but in the nonequivalent control group design the experimental group or control group is not randomly selected. This design can be described as follows:

\section{Picture 1. Research Design}

\begin{tabular}{|lll|}
\hline 01 & $\mathrm{X}$ & $\mathrm{O} 2$ \\
$\mathrm{O3}$ & & $\mathrm{O4}$ \\
\hline
\end{tabular}

\section{Information :}

O1: pretest result to experiment, class,

$\mathrm{O} 2$ : posttest result to experiment, class,

O3: pretest result to control class

O4: posttest result to control class

$\mathrm{X}$ : treatment by using a problem posing learning model[10].

The research design conducted was given a pretest to determine the student's initial ability, followed by giving treatment in the form of problem posing learning model in the experimental class and the last by giving the final test (posttest) to measure the student's understanding of the material after treatment. In the control, the class was also delivered pretest and then implement the learning by using STAD learning model, then conducting the final test (posttest). Pretest and posttest results that have been known then analyzed to draw a conclusion. In this study, the population was taken is all the fourth-grade students of SDN I Bogoran Kecamatan Kampak, Trenggalek. The population according to is the whole subject of the study. The total number of subjects has certain characteristics and qualities set by the researcher to be examined and then drawn a conclusion. The sample used was Class IV-A students with 20 students and Class IV-B students with 20 students[11].

In essence, in conducting research we must apply research instruments. According, research instruments are tools and facilities that can be used by researchers in collecting data. The instruments used in collecting data on this research were observation and test. Observations were made to collect data on learning activities in the learning process. Observations were conducted by researchers using the same instrument in the experimental class as well as the control class. While the test is a series of questions or exercises as well as other tools used to measure skills, intelligence knowledge, abilities or talent which possessed by individuals or groups. The test referred in this study is pretest and posttest with the number of questions every 20 questions. Technique or method used to collect data in this research were observation and using objective test (pretest and posttest). In this study, objective tests were administered to both the control group and the experimental group for pretest delivery to both groups: the control group and the experimental group were administered before the learning was conducted. It aims to know the student's early ability. While giving posttest 
problem to both groups was given after getting treatment in the form of Problem Posing learning model for experiment class and for control class using STAD learning model, it was aimed to know the final condition of both groups[12].

Data analysis technique begins from the instrument analysis using the technique of item validity namely a measure that indicates the level of validity or validity of an instrument. A valid instrument will have high validity and otherwise, a less valid instrument means it has low validity. Validity test was used to determine the eligibility of the items in a list of questions in defining a variable, therefore need to be tested by correlation test between the score of each item with the total score of the instrument. Instruments that used still cannot be judged "standard" in this research, so to avoid invalid data yielded hence first must test the instrument by conducting validity test. To determine validity, then it was applied product moment correlation technique. In this research the product moment formula is as follows:

Information:

$$
r_{x y}=\frac{N \sum X Y-\left(\sum X\right)\left(\sum Y\right)}{\sqrt{\left\{N \sum X^{2}-\left(\sum X^{2}\right)\right\}\left\{N \sum Y^{2}-\left(\sum Y^{2}\right)\right\}}}
$$

$r_{x y}=$ Correlation coefficient between variable $X$ and variable $\mathrm{Y}$

$\mathrm{N}=$ Number of students

$\mathrm{X}=$ Scores of each item

$\mathrm{Y}=$ Total score

Decision Rule is: if $r_{\text {count }}>r_{\text {table }}$ at $5 \%$ significance level that means the item is valid and if $r_{\text {count }}<r_{\text {table }}$ at $5 \%$ significance level means the item is not valid.

The next test data was a reliability test, Reliability refers to the reliability level of something. Something is an instrument, something quite trustworthy instrument to use as a data gathering tool because the instrument is good. Reliability test in this research used Spearman-Brown formula. The spearman-brown formula is a formula that uses a halved technique. The half two referred in the Spearman-Brown formula were the odd scores and even scores. The following is the formula to obtain reliability index questions:

\section{Information:}

$$
\mathrm{r}_{11}=\frac{2 \mathrm{xr}_{1 / 21 / 2}}{\left(1+\mathrm{r}_{1 / 21 / 2}\right)}
$$

$\mathrm{r}_{11} \quad=$ instrument reliability

$r_{1 / 21 / 2}=r_{x y}$ which called the correlation index between two hemispheres of the instrument

The criteria in Spearman-Brown reliable calculation was using a 0.6 with the criterion of calculation is if the value of $r>$ of 0.6 then the instrument is good or reliable and vice versa if the value of $r<0.6$ then the instrument is not good or not reliable[13].

After performing the instrument analysis test then the next was to test the data analysis starting from the homogeneity test, used to determine whether the selected sample has the same variety (homogeneous) or not.
Homogeneous samples in this study referred to have the level of ability and characteristics that almost same. The formula used to test the variant homogeneity was followed:

$$
\begin{aligned}
& \text { Information: } \\
& \begin{array}{ll}
\mathrm{SD}^{2} & =\text { value of variant } \\
\Sigma \mathrm{X}^{2} & =\text { amount of } \mathrm{X} 2 \text { data } \\
\Sigma \mathrm{X} & =\text { amount of data } \mathrm{X} \\
\mathrm{N} & =\text { sum of all data }
\end{array}
\end{aligned}
$$$$
\text { Varian }\left(\mathrm{SD}^{2}\right)=\frac{\sum \mathrm{x}^{2}-\left(\sum \mathrm{x}\right)^{2} / \mathrm{N}}{(\mathrm{N}-1)}
$$

After obtaining the value of $F_{\text {count }}$, then make a comparison with the criteria:

If $\mathrm{F}_{\text {count }}<\mathrm{F}_{\text {table, }}$, it mean homogeneous.

If $\mathrm{F}_{\text {count }}>\mathrm{F}_{\text {table, }}$ it means not homogeneous.

The next data analysis was to calculate the normality of the pretest and posttest data of experimental class and control class. Normality test aims to determine whether the data obtained has distributed normally or not. Normality test is a requirement that must be met to determine the test statistics to be used. In this study, the researchers calculated the normality test using the Chi-square formula as follows:

Information:

$$
x^{2}=\Sigma\left[\frac{(f o-f e)^{2}}{f e}\right]
$$

$$
\begin{array}{ll}
x^{2} & =\text { chi-square value } \\
\text { fo } & =\text { the frequency obtained } \\
\text { fe } & =\text { expected frequency }
\end{array}
$$

By using Chi-Square formula, if $\mathrm{X}^{2}$ count obtained was greater than $\mathrm{X}_{\text {tabel }}^{2}$ in the table then the data obtained is not normally distributed. And vice versa if the price of $X^{2}$ count obtained was smaller than $X^{2}$ table in the table, it means the data we get is in a normal distribution.

The next test data was a t-Test, it was used to test the significance of the difference between the control class and the experimental class by comparing the activity and learning outcomes before and after treatment. This is in accordance with the opinion of The t-Test technique is a statistical technique used to test the significance of the difference between two means derived from two pieces of distribution". The formula used to calculate the t-Test is as follows:

$$
t \text {-test }=\frac{M_{X}-M_{Y}}{\sqrt{\left(\frac{\sum x^{2}+\sum y^{2}}{N_{x}+N_{y}-2}\right)\left(\frac{1}{N_{x}}+\frac{1}{N_{y}}\right)}}
$$

\section{Information:}

$$
\begin{array}{ll}
M_{X} & =\text { the mean of the difference of control class score } \\
M_{Y} & =\text { the mean of experiment class grade score } \\
\mathrm{N} & =\text { number of subjects } \\
\mathrm{x} & =\text { deviation of each } \mathrm{x}_{1} \text { and } \mathrm{x}_{2} \text { values } \\
\mathrm{y} & =\text { deviation of each } y_{1} \text { and } y_{2} \text { values }
\end{array}
$$

After the value of t-Test was determined, then the next step was looking for degrees of freedom with the formula 
d.b. $=(\mathrm{Nx}+\mathrm{Ny}-2)$ and consult with a table at the 0.05 significance level. If $t_{\text {count }}>$ table then it can be concluded that the delivered treatment affects the activity and student learning outcomes and if $t_{\text {count }}<t_{\text {tabel }}$ then it will found out that the treatment delivered by researchers did not affect the activity and student learning outcomes[14].

\section{RESULTS AND DISCUSSION}

The research results that have been conducted on the calculation of problem validity test. Researchers use data test results that calculated by product moment correlation formula. If the values of $r_{x y}>$ table then the problem said to be valid with a significant level of $5 \%$.

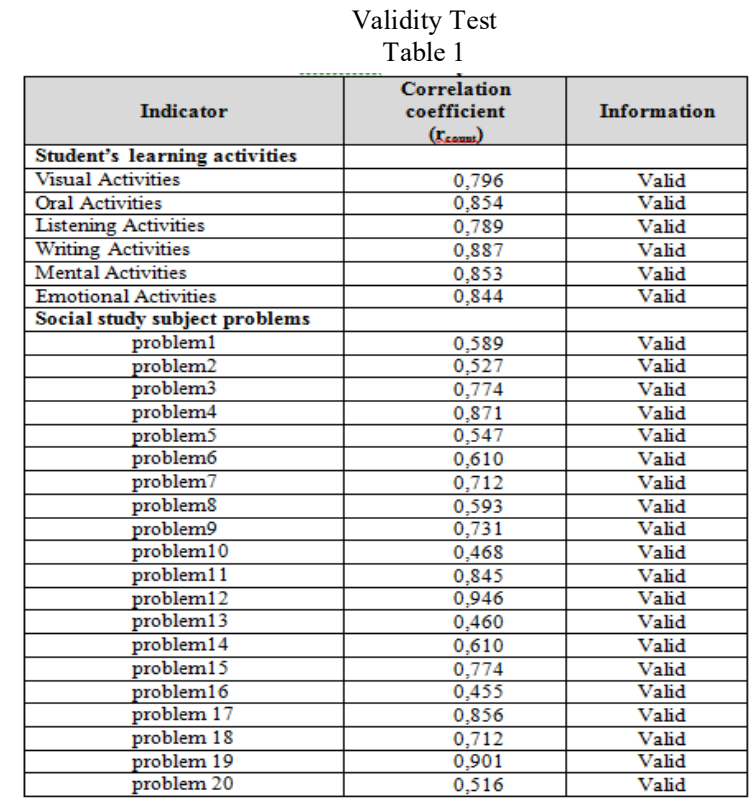

The next test was reliability test, which related to the determination or the rigour of a research instrument in assessing what is judged, meaning that whenever the assessment instrument used it will give relatively the same result. The results of the reliability test of learning activities and learning outcomes were:

$$
\begin{gathered}
\text { Reliability Test of Research Variables } \\
\text { Table } 2
\end{gathered}
$$

\section{Research variable Student's learning activities Student's Learning Outcome}

Guttman Split-Half Coefficient
0,657
0,946

The results of the reliability test on learning activity variables and student learning outcomes resulted in Guttman Split-Half Coefficient with a value of more than 0.6. Thus, it can be seen that the variable learning activities and student learning outcomes in this study were reliable.

\section{Data Normality Test}

Normality test was done on data of student learning activity when given treatment as well as on pretest and posttest with the objective to determine the normality of data distribution. Normality test data was calculated by using chisquare test with normality test criteria that if significance $<0.05$, then the data was not normally distributed if the significance value $>0.05$, then the data was normally distributed. The results of the normality test activity data and learning outcomes in this study were as follows.

Student's Learning Activities Data Normality Test Results Table 3

\begin{tabular}{|l|c|c|c|}
\hline \multicolumn{1}{|c|}{ Group } & Variable & $\begin{array}{c}\text { chi-square } \\
\text { test }\end{array}$ & $\begin{array}{c}\text { Information } \\
\text { (Asymp. Sig. > 0,05) }\end{array}$ \\
\hline Control & Learning Activity & 0,609 & Normal \\
\hline Experiment & Learning Activity & 0,796 & Normal \\
\hline
\end{tabular}

Data on table 3 based on the results of student learning activities test both in control and experimental class and it was known that the significance (Sig.) Value is 0.609 and 0.796 . So it can be concluded that the significance value (Sig.) $>0.05$ which means the data was normally distributed.

Student's Learning Results Normality Data Test Results Table 4

\begin{tabular}{|c|c|c|c|}
\hline \multirow{2}{*}{ Group } & Variable & chi-square test & $\begin{array}{c}\text { Information } \\
\text { (Asymp. Sig. }>0,05)\end{array}$ \\
\hline \multirow{2}{*}{ Control } & Pretest & 0,518 & Normal \\
\cline { 2 - 4 } & Posttest & 0,524 & Normal \\
\hline \multirow{2}{*}{ Experiment } & Pretest & 0,537 & Normal \\
\cline { 2 - 4 } & Posttest & 0,548 & Normal \\
\hline
\end{tabular}

Data from table 4 based on the test results it was found out that the significance value (Sig.) Pretest score of control and experimental groups from student learning outcomes was 0.518 and 0.537 . Thus, pretest data in both classes were normally distributed. In the posttest test results, it was found out that the significance (Sig.) of the students' learning outcomes on control class and experimental class were 0.524 and 0.548 . It can be concluded that the significance value (Sig.) $>$ was 0,05 which means posttest in both classes is a normal distribution.

\section{Homogeneity Test}

Homogeneity test was done on the data of student's learning activity when given treatment and pretest and posttest with the aim to know whether data has the same data variant (homogenous) or different. The homogeneity test of the data was calculated using the Lavene's Test. The homogeneity test results of student's activity and learning outcomes data in this study were as follows.

Homogeneity Test Results of Student Learning Activity Data Table 5

\begin{tabular}{|c|c|c|c|c|}
\hline Levene Statistic & $\mathrm{df1}$ & $\mathrm{df2}$ & Sig. & $\begin{array}{c}\text { Information } \\
(\text { Asymp. Sig. }>0,05)\end{array}$ \\
\hline 0,286 & 1 & 38 & 0,596 & Homogenous \\
\hline
\end{tabular}

Based on table 5 test results it was found out that the significance (Sig.) score of learning activities from control class and the experimental class was 0,596>0,05 which showed that data have the same or homogeneous variant. 
Homogeneity Test Results of Student Learning Data Table 6

\begin{tabular}{|l|c|c|c|c|c|}
\hline & Levene Statistic & $\mathrm{df1}$ & $\mathrm{df} 2$ & Sig. & $\begin{array}{c}\text { Information } \\
\text { (Asymp. Sig. }>0,05)\end{array}$ \\
\hline Pretest & 0,345 & 1 & 38 & 0,561 & Homogeneous \\
\hline Posttest & 0,057 & 1 & 38 & 0,813 & Homogeneous \\
\hline
\end{tabular}

Based on the test result it can be found out that the signification value (Sig.) of student's learning outcome data on pretest (control and experiment classes) it was $0.561>0.05$ that showed pretest data has the same variant (homogenous). On posttest result, it was found out that signification (Sig.) of student's learning outcome data (control and experiment classes) was $0.813>0.05$ which mean that posttest data has the same variant (homogenous).

The Data Before Treatment Of t-Test Result

t-Test Result Of Student's Learning Outcome Data Table 7

\begin{tabular}{|c|c|c|c|c|}
\hline$T_{\text {count }}$ & $\mathrm{t}_{\text {table }}$ & $\mathrm{Df}$ & Sig. (2-tailed) & $\alpha$ \\
\hline 1,141 & 2,024 & 38 & 0,268 & 0,05 \\
\hline
\end{tabular}

Based on t-Test results in table 7 , it can be seen that count for data pretest result of student learning outcome (control class and experiment class) was equal to 1,141 (df 38) and Sig. (2-tailed) of 0.268. For more details t-Test results in pretest data student learning outcomes, it can be seen in the appendix. The results showed that count 1.141 (df 38) $<\mathrm{t}_{\text {table }} 2.024$ (df 38) and Sig value. (2-tailed) $0.268>0.05$ which means Ho was accepted and $\mathrm{Ha}$ rejected. Thus, there was no significant difference between the students' learning outcomes in the control class and the students in the experimental class.

\section{t-Test Data Result After Treatment}

The hypothesis test result of student learning activity data at the time of complete treatment is in the attachment below. While in summary can be seen in table 8 below.

Hypothesis Test Results of Student Learning Activity Data

\begin{tabular}{|c|c|c|c|l|}
\hline $\mathrm{T}_{\text {count }}$ & $\mathrm{t}_{\text {table }}$ & $\mathrm{df}$ & Sig. (2-tailed) & \multicolumn{1}{l|}{ a } \\
\hline 3,433 & 2,024 & 38 & 0,003 & 0,05 \\
\hline
\end{tabular}

Based on the result of t-Test in table 8 , data of student learning activity during treatment (control class and experiment class) it can be seen that $t_{\text {count }}$ equal to 3,433 (df 38 ) and Sig value. (2-tailed) as big as 0.003 . These result showed that $\mathrm{t}_{\text {count }}$ was 3.433 (df 38) $>$ ttab2le 2.024 (df 38) and Sig value. (2-tailed) $0.003<0.05$ which means that Ho was rejected and $\mathrm{Ha}$ accepted. There were significant differences in student learning activities in the control class and experimental class. So it can be concluded that there was a significant effect of Problem Posing learning model to learning activities in the social studies subject for fourth-grade elementary school students.

The hypothesis test result of student learning result data on posttest is attached in the appendix. While in summary can be seen in table 9 below.

Hypothesis Test Results Student Learning Results Posttest Data Table 9

\begin{tabular}{|c|c|c|c|c|}
\hline$T_{\text {count }}$ & $\mathrm{t}_{\text {table }}$ & $\mathrm{df}$ & Sig. (2-tailed) & $\alpha$ \\
\hline 3,290 & 2,024 & 38 & 0,004 & 0,05 \\
\hline
\end{tabular}

Based on t-Test result at table 9, posttest result data of student learning (control class and experiment class) was $t_{\text {count }} 3,290$ (df 38) and Sig value. (2-tailed) by 0,004 . The result showed that $t_{\text {count }} 3,290$ (df 38) $>$ ttable 2.024 (df 38) and Sig value. (2-tailed) $0.004<0.05$ which means Ho was rejected and $\mathrm{Ha}$ accepted. There were significant differences in student learning outcomes in the control class and experimental class. So it can be concluded that there was a significant effect of the Problem Posing learning model to student learning outcomes in the social studies subjects of fourth-grade students of elementary school.

\section{RESULTS AND DISCUSSION}

In the analysis result of student's learning activity, $\mathrm{t}$ Test obtained result namely $t_{\text {hing }} 3,433$ (df 38) $>t_{\text {table }} 2.024$ (df 38) So, it can be concluded that the posing problems learning model affect student learning activity.

In the analysis result posttest of student learning outcomes, $t$-test that obtained namely $t_{\text {count }} 3,290(\mathrm{df} 38)>t_{\text {table }}$ 2,024 (df 38). So, it can be concluded that the posing problems learning model affect student learning outcomes.

\section{REFERENCES}

[1] Shriki, Atara. A Model for Assessing the Development of Students' Creativity in the Context of Problem Posing. Creative Education. Vol.4, No.7.2013.

[2] Wrech, JasonCommunication Affect And Learning In The Classroom. Journal Of International Social Studies, Vol. 23, No. 40.2009.

[3] Acar, Filis Evran.An Assessment Of Social Studies Competency Of Turkish Classroom Teachers. Journal Of Instruction, Vol. 1, No. 2. 2008.

[4] Kaba, Yasemin., Sare, Sengul. Developing the Rubric for Evaluating Problem Posing International Online Journal of Educational Sciences. Vol. 8, No. 1.2016.

[5] Ozdemir, Ahmet Sukru.Comparative Analysis Of Problem Posing Ability Between The Anatolian High School Students And The Public High School Students Located In Bagcilar District Of Istanbul. Social And Behavioral Sciences. Vol. 21, No. 6. 2012.

[6] Guvercin, Selim., Verbovskiy, Viktor. The Effect Of Problem Posing Tasks Used In Mathematics Instruction To Mathematics Academic Achievement And Attitudes Toward Mathematics. Kazakhstan: International Online Journal Of Primary Education. Vol. 3, No. 2. 2014.

[7] Sayed, Reda Abu-Elwan El. Effectiveness Of Problem Posing Strategies On Prospective Mathematics Teachers' Problem Solving Performance. Oman: Journal Of Science And Mathematics Education In S.E. Asia. Vol. XXV, No. 1. 2012.

[8] Egan, Cate A. Partnerships For Active Children In Elementary Schools (PACES): First Year Process Evaluation. Evaluation And Program Planning. Vol. 67 No. 20. 2011.

[9] Kennedy, Ruth. In-Class Debates Fertile Ground For Active Learning And The Cultivation Of Critical Thinking And Oral Communication Skill. International Journal Of Teaching And Learning In Higher Education. Vol. 19 No. 2. 2009.

[10] Sugiyono. Metode Penelitian Pendidikan Pendekatan Kuantitatif, Kualitatif, dan R \& D. Bandung : Alfabeta. 2015.

[11] Arikunto, Suharsimi. Prosedur Penelitian Suatu Pendekatan Praktik. Jakarta: Rineka Cipta. 2010. 
[12] Sujarweni, V. Wiratna, Metodologi Penelitian Lengkap, Praktis dan Mudah Dipahami. Yogyakarta: Pustakabarupres. 2014

[13] Winarsunu, T. Statistik dalam Penelitian Psikologi dan Pendidikan. Edisi Revisi. Malang: UMM Press Malang. 2012.
[14] Rostina, Sundayana. Statistika Penelitian Pendidikan. Alfabeta, Bandung.2014 